\title{
Rituximab-associated progressive multifocal leukoencephalopathy
}

\author{
Juraj Sokol' ', Lenka Lisá', Jana Zeleňáková2, Tomáš Balhárek³, Ivana Plameňová', Ján Staško', Peter \\ Kubisz ${ }^{1}$ \\ 'Department of Haematology and Transfusion Medicine, National Centre of Haemostasis and Thrombosis, Jessenius Faculty of \\ Medicine in Martin, Comenius University in Bratislava, Slovakia \\ 2Department of Neurology, Jessenius Faculty of Medicine in Martin, Comenius University in Bratislava, Slovakia \\ ${ }^{3}$ Department of Pathological Anatomy, Jessenius Faculty of Medicine in Martin, Comenius University in Bratislava, Slovakia
}

\section{Summary}

The definition "Progressive Multifocal Leukoencephalopathy" (PML) was first used in 1958 to describe a fatal demyelinating central nervous system (CNS) disease in patients with lymphoproliferative disorders. In 1971, the virus responsible for the disease was isolated and named John Cunningham virus (JCV). We present a rare case of a 62-year-old male with chronic lymphocytic leukemia and PML. In our work, we discuss the diagnostic and therapeutic challenges and offer suggestions for preventing PML development. The main learning points are: 1 . Regularly check the level of immunoglobulins and the $\mathrm{CD}^{+}: \mathrm{CD}^{+} \mathrm{T}$-cell ratio, intravenous administration of immunoglobulins should be considered when recording their reduction. 2 . In checking the $C D 4^{+}: \mathrm{CD}^{+} \mathrm{T}$-cell ratio and verifying the impossibility of raising the level of immunoglobulins, we must weigh the possible benefits of continuing treatment with monoclonal antibody against the risks. 3. Physicians should maintain a high index of suspicion for the development of PML in patients under treatment with monoclonal antibodies, especially when there is a new development of neurological signs or symptoms.

Key words: JC virus - progressive multifocal leukoencephalopathy - recommendation - rituximab

\section{Progresivna multifolkálna leukoencefalopatia spojená s rituximabom}

\section{Súhrn}

Progresívna multifokálna leukoencefalopatia (PML) bola prvýkrát popísaná v roku 1958 u pacienta s lymfoproliferatívnym ochorením. V roku 1971 bol izolovaný John Cunninghamov vírus (JCV), ktorý je zodpovedný za vznik tohto ochorenia. $V$ našej práci popisujeme raritný prípad 62-ročného pacienta s chronickou lymfocytovou leukémiou a PML. Zároveň diskutujeme o diagnostických a terapeutických výzvach a ponúkame návrhy prevencie rozvoja PML. Hlavnými závermi práce sú: 1. Potrebný je pravidelný monitoring sérových hladín imunoglobulínov a pomeru $\mathrm{CD}^{+}$: $\mathrm{CD} 8^{+}$T-lymfocytov, podanie intravenóznych imunoglobulínov je potrebné zvážit pri ich poklese. 2. Pri poklese pomeru $C D 4^{+}: C D 8^{+}$T-lymfocytov a nemožnosti podat intravenózne imunoglobulíny musíme zvážit pokračujúci prínos podávania imunoterapie. 3. Pri objavení sa neurologickej symptomatológie u pacienta, ktorý podstupuje imunosupresívnu liečbu, musí lekár vyslovit podozrenie na možný rozvoj PML.

Klúčové slová: JC vírus - odporúčanie - progresívna multifokálna leukoencefalopatia - rituximab

\section{Introduction}

The definition "Progressive Multifocal Leukoencephalopathy" (PML) was first used in 1958 to describe a fatal demyelinating central nervous system (CNS) disease in patients with lymphoproliferative disorders [1]. In 1971 , the virus responsible for the disease was isolated and named John Cunningham virus (JCV) [2]. The JCV is a common and widespread agent; however, most of the JC virus seropositive individuals remain clinically asymptomatic. Sero-epidemiological studies indi- cate that the JCV has a worldwide distribution occurring generally at an early age $(<20$ years). The reported seroprevalence of JCV varies throughout the literature, ranging from $33 \%$ to more than $90 \%$. Following the initial infection, the virus becomes dormantin certain tissues such as kidneys, lymphoreticular tissues, or brain. The exact mechanisms of viral transmission and development of PML remain only partially understood. Primary infection of the CNS following suppression of the immune response versus reactivation of a dormant in- 
fection in the CNS, are among the proposed hypotheses [3-9].

The classic form of PML has a fulminating evolution usually leading to death within a few months. The onset is usually multisymptomatic and the most common clinical presentation includes motor deficits, altered consciousness, gait ataxia and visual symptoms [10]. Atypical presentations, usually reported in human immunodeficiency virus-infected patients after the introduction of combination antiretroviral therapy, include pure cerebellar syndrome, reflecting a productive infection of granule cell neurons [11], meningitis [12], meningoencephalitis [13,14], progressive myoclonic ataxia [15] and muscle wasting associated with extrapyramidal signs [16].

Recently, several cases of PML related to the use of new immunomodulatory drugs for the treatment of lymphoproliferapive diseases were reported. Therefore, we need to identify clinical risk factors that help us prevent PML development.

\section{Case presentation}

The patient is a 62-year-old man who presented with B-cell chronic lymphocytic leukaemia (B-CLL). In 2006 diagnosis of CLL, Rai Stage III, Binet Stage C. Principal characteristics at diagnosis: haemoglobin level $105 \mathrm{~g} / \mathrm{l}$, white blood cells $15.8 \times 10 \% /$, lymphocytes $64 \%$, neutrophils $29 \%$, monocytes $4 \%$, platelets $154 \times 10^{9} /$; normal hepatic end renal function; flowcytometric immunophenotyping of the peripheral blood revealed B-cell CLL; prognostic factors: CD38 negative, ZAP70 positive, rearrangement of the immunoglobulins mutated; FISH: negative; CT chest/abdomen/pelvis: presence of multiple aorto-pulmonary and axillary adenopathies (maximal diameter of $2 \mathrm{~cm}$ ); bone marrow biopsy: infiltration of CLL equal to $65 \%$ of global cellularity. He also had a medical history of glaucoma, hypertension and hypercholesterolemia.

The patient underwent 4 cycles of first-line COP chemotherapy, consisting of cyclophosphamide, vincristine and prednisone. Partial remission was achieved and the patient was on maintenance therapy with chlorambucil for 5 years. Second-line COP chemotherapy with anti-CD20 monoclonal antibody (rituximab; dose 700 mg every 3 weeks) was utilised because of B-CLL progression (anaemia and B-symptoms). After the application of the third cycle of immunochemotherapy (10 days), the patient was hospitalized with ischemic stroke and quadriparesis with left predominance at Department of Neurology. Therefore, immunochemotherapy was not given for three months. Magnetic resonance imaging (MRI) scans showed several cortical and subcortical lesions in the frontal and parietal lobes bilaterally (fig. $1-1 \mathrm{~A}, 1 \mathrm{~B})$.

The damaging effects were explained by post-ischemic changes, but observation was recommended. The fourth cycle of immunochemotherapy was complicated with acute bronchitis, successfully treated with antibiotics and application of intravenous immunoglobulin, no other infectious complications occurred during the treatment. After resolving these infectious complications, we submitted for the fifth cycle of immunochemotherapy. However, neurological complications (dysarthria, disorientation and personality deterioration) discovered during this treatment, which were interpreted as toxicity from the immunochemotherapy in combination with a recent history of ischemic vascular events. Due to this fact and the fact that the patient achieved remission, we decided to stop the immunochemotherapy. A brain MRI was completed and the scans showed that existing lesions continued to enlarge and a new lesion appeared in the white matter (fig. 1 -2A, 2B).

Fig. The MRI scans

1A, 1B: The MRI scans showed cortical brain atrophy, several cortical and subcortical lesions in the frontal and parietal lobes bilaterally. The increased signal intensity in fluid-attenuated inversion recovery (FLAIR) sequence on the gyrus surfaces in the both parietal lobes and in the left occipital lobe without hypervascularization.

2A, 2B: The MRI FLAIR scans showed that existing lesions continued to enlarge and new lesion appeared in the white matter of the right occipital lobe.

3A, 3B. The MRI FLAIR scans showed extensive merged lesions bilaterally and hypervascularized temporal lobes.

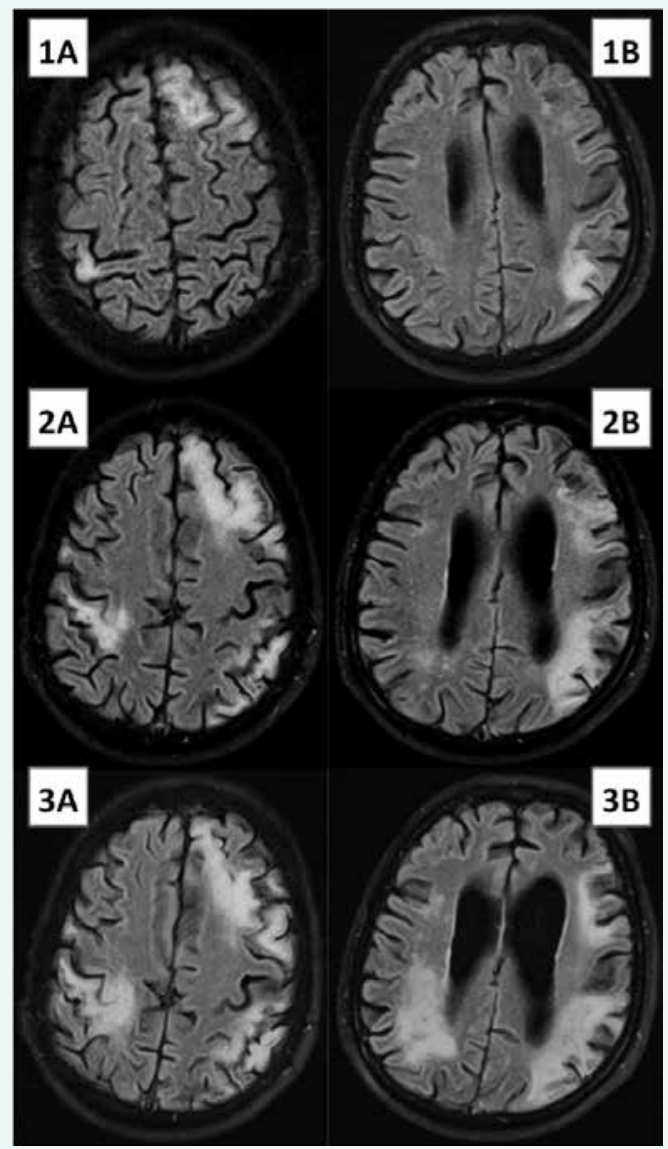


One month later, the patient was hospitalised in the Department of Neurology with a history of dysarthria, vertigo, gait, central quadriparesis accented on the left side and ataxia. The MRI was repeated and it showed evidence of suspected chronic lymphocytic leukemic meningeal infiltration. Therefore, the patient was transferred to the Department of Haematology. The main neurological symptoms after the transport were somnolence, eyes open in response to voice, verbal response consisting of just moaning but no words, left-sided hemiplegia, flexion/extension hyperkinetic movements of the right limbs, dilated pupils bilaterally, fronto-orbicular, corneal and gag reflex were present, Babinski reflex was positive on both sides. In view of the inconsistency of clinical manifestations, MRI findings were reviewed (fig. 1 - 3A, 3B). After consultation with neurologists and radiologists, the possibility of PML was suspected. Polymerase chain reaction (PCR) analysis of cerebrospinal fluid revealed JCV infection and diagnosis of PML was confirmed. The test for antigen and antibodies to human immunodeficiency virus (HIV) was not carried out.

\section{Investigation}

PML can be suspected by typical presentation with focal neurological deficits and corresponding demyelinating lesions MRI. Definitive diagnosis requires identification of JCV in cerebrospinal fluid or brain tissue [17]. All findings from these tests are at the text above. In this section, we would like to draw attention to the gradual consistent deepening of the immunodeficiency state from 2006 to 2012. However, we observed a decrease in white blood cell count in 2012 (the range is between $<4 \times 10^{9} / \mathrm{l}$ to $>2.5 \times 10^{9} / \mathrm{l}$ ). Larger decreases are recorded in the level of immunoglobulin, especially in the $\lg G$ and $\lg A$ types (tab). After the death of patient, the brain biopsy showed a demyelinating process (fig. 2).

\section{Differential diagnosis}

Many conditions can produce a multifocal CNS syndrome with a progressive course. During the last hospitalization, the condition of the patient was consulted with a neurologist, radiologist and hematologist again.
Radiologist revised the previous conclusions. He excluded CNS lymphoma infiltration and post-ischemic changes. Progressive deterioration of neurologic and mental status and CNS imaging changes could indicate PML. Therefore, the PCR analysis of cerebrospinal fluid

\section{Fig. 2. Brain biopsy}

4A. PML demyelination lesion in white matter near gray-white junction (Luxol blue staining, 200x)

4B. Area of demyelination in white matter - bizarre atypical or enlarged infected astrocytes with intranuclear inclusions (arrow), gemistocytic atrocytes and lipid-laden macrophages (arrowhead) (HE, 400×)

4C. White matter - activation and enlargement of oligodendroglial cells ( $\mathrm{HE}, 400 \times)$

4D. White matter - enlarged ballooned oligodendroglial cells with dark pink inclusions (arrows) (HE, 400X)

4E. Gray matter - pericellular and perivascular oedema, perivascular inflammatory lymphoid infiltrate as feature of viral infection (HE, 200x)

4F. Gray matter - features of neuronophagia ( $\mathrm{HE}, 400 \times)$
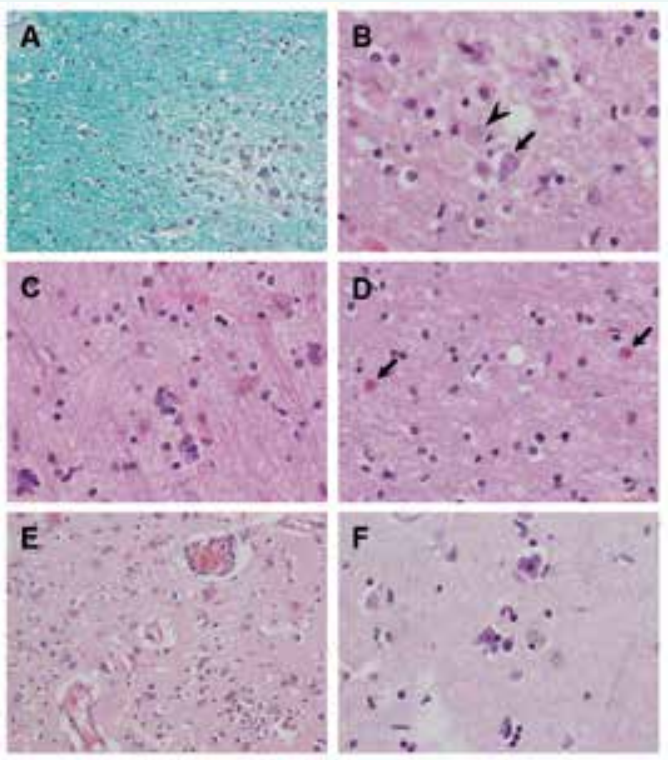

Tab. Development of white blood cell count and immunoglobulin level

\begin{tabular}{|c|c|c|c|c|c|}
\hline & $\begin{array}{l}\text { partial } \\
\text { remission }\end{array}$ & $\begin{array}{l}1^{\text {st }} \text { cycle of } \\
\text { chemotherapy } \\
\text { with rituximab }\end{array}$ & $\begin{array}{c}3^{\text {rd }} \text { cycle of } \\
\text { chemotherapy } \\
\text { with rituximab }\end{array}$ & $\begin{array}{l}4^{\text {th }} \text { cycle of } \\
\text { chemotherapy } \\
\text { with rituximab }\end{array}$ & $\begin{array}{c}\text { progressive } \\
\text { multifocal } \\
\text { leukoence- } \\
\text { phalopathy }\end{array}$ \\
\hline imunoglobulin G (normal value: 7-16 g/l) & 11.6 & 8.7 & 5.9 & 5.8 & 3.3 \\
\hline imunoglobulin A (normal value: 0.7-4 g/l) & 2.9 & 3.3 & 1.5 & 1.5 & 0.8 \\
\hline imunoglobulin M (normal value: $0.4-2.3 \mathrm{~g} / \mathrm{l}$ ) & 0.6 & 0.39 & 0.2 & 0.14 & 0.06 \\
\hline neutrophils $\times 10^{9} / \mathrm{l}$ (normal value: $\left.2-7.5 \times 10^{9} / \mathrm{l}\right)$ & 5.1 & 4.7 & 5.5 & 5.3 & 3.1 \\
\hline lymphocytes ×109/I (normal value: $\left.1-4.8 \times 10^{9} / \mathrm{I}\right)$ & 9.1 & 3.1 & 8.9 & 2.7 & 1.1 \\
\hline hemoglobin level (normal value: 135-175 g/l) & 153 & 114 & 111 & 126 & 108 \\
\hline platelets $\times 10^{9} / \mathrm{l}$ (normal value: $\left.150-350 \times 10^{9} / \mathrm{I}\right)$ & 150 & 154 & 185 & 150 & 198 \\
\hline
\end{tabular}


was performed. The brain biopsy was performed after death of the patient.

\section{Treatment}

There is no specific treatment for JC virus. 24 hours after we got the JCV positive results, patient received bacterial pneumonia. Complex supportive care was given to our patient, including antibiotic therapy and intravenous immunoglobulins. Unfortunately, the patient died of complications from pneumonia after two weeks of PML diagnosis.

\section{Discussion}

To our knowledge, this is the first article about PML in a patient with CLL treated with rituximab in Central and Eastern Europe. In this section, we also offer some suggestions for preventing PML development.

At present, more than 70 cases of PML have been associated with the use of rituximab [18-21], predominantly in patients with lymphoproliferative disorders. The risk quantification of PML related to the use of rituximab is difficult. Rituximab is a chimeric lgG1 that links to CD20 and it induces a severe depletion of B-lymphocytes. Some research suggests that the occurrence of $\mathrm{PML}$ in the context of B-lymphocyte depletion are not the principal vehicle for JCV to enter the brain, but also that the humoral immunity might play a role in the control of JCV replication [22]. Therefore, we think that it is important to check the levels of immunoglobulins in the body and intravenous administration of immunoglobulins should be considered when we record their reduction. Another way to verify the immunological status of the patient is by checking the $\mathrm{CD}^{+}: \mathrm{CD}^{+} \mathrm{T}$-cell ratio. $A$ reduction of the $\mathrm{CD}^{+}: \mathrm{CD} 8^{+}$T-cell ratio might facilitate the occurrence of PML [10]. By a reduction of this ratio and the impossibility of raising the level of immunoglobulins, we must weigh possible benefits of continuing treatment with monoclonal antibody therapy against the risks. A final most important recommendation is to consider the possibility of PML in patients treated with monoclonal antibodies and in whom new neurological signs or symptoms develop. All these findings should be confirmed by further research.

\section{Conclusion}

We recommend:

- regularly check the level of immunoglobulins and the $\mathrm{CD}^{+}$: CD8 ${ }^{+}$T-cell ratio (normal range is $0.9-1.9$ ), intravenous administration of immunoglobulins should be considered when recording their reduction

- in checking the $\mathrm{CD} 4^{+}: \mathrm{CD} 8^{+} \mathrm{T}$-cell ratio and verifying the impossibility of raising the level of immunoglobulins, we must weigh the possible benefits of continuing treatment with monoclonal antibody against the risks

- physicians should maintain a high index of suspicion for the development of PML in patients under treatment with monoclonal antibodies, especially when there is a new development of neurological signs or symptoms, the cerebrospinal fluid should be examined by atypical and inconsistent clinical and radiological findings

- the test for antigen and antibodies to HIV should be performed in every patient with suspected PML

\section{References}

1. Aström KE, Mancall EL, Richardson EP. Progressive multifocal encephalopathy: a hitherto unrecognized complication of chronic lymphocytic leukemia and lymphoma. Brain 1958; 81: 93-111.

2. Padgett BL, Walker DL, Zu Rhein GM et al. Cultivation of papova-like virus from human brain with progressive multifocal leukoencephalopathy. Lancet 1971; 1(7712): 1257-1260.

3. Major EO, Amemiya K, Tornatore CS et al. Pathogenesis and molecular biology of progressive multifocal leukoencephalopathy, the JC virus-induced demyelinating disease of the human brain. Clin Microbiol Rev 1992; 5(1): 49-73.

4. Isella V, Marzorati L, Curto $\mathrm{N}$ et al. Primary progressive multifocal leukoencephalopathy: report of a case. Funct Neurol 2005; 20(3): 139-142.

5. Knowles WA, Pipkin P, Andrews $\mathrm{N}$ et al. Population-based study of antibody to the human polyomavirusesBKV and JCV and the simian polyomavirus SV40. J Med Virol 2003; 71(1): 115-123.

6. Egli A, Infanti L, Dumoulin A et al. Prevalence of polyomavirus BK and $J C$ infection and replication in 400 healthy blood donors. J Infect Dis 2009; 199(6): 837-846.

7. Stolt A, Sasnauskas $K$, Koskela $P$ et al. Seroepidemiology of the human polyomaviruses. J Gen Virol 2003; 84(Pt 6): 1499-1504.

8. Berger JR, Major EO. Progressive multifocal leukoencephalopathy. Semin Neurol 1999; 19(2): 193-200.

9. Táborský P, Hrabánek J, Matl I et al. Progresivní multifokální leukoencefalopatie u nemocné po transplantaci ledviny. Vnitř Lék 1998; 44(2): 108-110.

10. Tavazzi E, Ferrate $P$, Khalili K Progressive multifocal leukoencephalopathy: an unexpected complication of modern therapeutic monoclonal antibody therapies. Clin Microbiol Infect 2011; 17(12): 1776-1780. Dostupné z DOI: <http://dx.doi.org/10.1111/j.1469-0691.2011.03653. $x>$.

11. Koralnik IJ, Wüthrich $C$, Dang $X$ et al. JC virus granule cell neuronopathy: a novel clinical syndrome distinct from progressive multifocal leukoencephalopathy. Ann Neurol 2005; 57(4): 576-580.

12. Viallard JF, Ellie $E$, Lazaro $E$ et al. JC virus meningitis in a patient with systemic lupus erythematosus. Lupus 2005; 14(12): 964-966.

13. Behzad-Behbahani A, Klapper PE, Vallely PJ et al. BKV-DNA and JCV-DNA in CSF of patients with suspected meningitis or encephalitis. Infection 2003; 31(6): 374-378.

14. Blake $K$, Pillay $D$, Knowles $W$ et al. JC virus associated meningoencephalitis in an immunocompetent girl. Arch Dis Child 1992; 67(7): 956-957.

15. Fontoura $P$, Vale J, Lima $C$ et al. Progressive myoclonic ataxia and $J C$ virus encephalitis in an AIDS patient. J Neurol Neurosurg Psychiatry 2003; 72(5): 653-656.

16. Tallantyre EC, Paine SM, Sharp CP et al. Atypical progressive multifocal leukoencephalopathy associated with an unusual JC polyomavirus mutation. Arch Neurol 2009; 66(8): 1021-1024. Dostupné z DOI: <http://dx.doi.org/10.1001/archneurol.2009.94>.

17. Cinque $\mathrm{P}$, Koralnik IJ, Gerevini $\mathrm{S}$ et al. Progressive multifocal leukoencephalopathy in HIV-1 infection. Lancet Infect Dis 2009; 9(10): 625-636. Dostupné z DOI: <http://dx.doi.org/10.1016/ S1473-3099(09)70226-9>.

18. Goldberg SL, Pecora AL, Alter RS et al. Unusual viral infections (progressive multifocal leukoencephalopathy and cytomegalovirus disease) after high-dose chemotherapy with autologous blood stem cell rescue and peritransplantation rituximab. Blood 2002; 99(4): 1486-1488. 
19. Carson KR, Evens AM, Richey EA et al. Progressive multifocal leukoencephalopathy following rituximab therapy in HIV negative patients: a report of 57 cases from the Research on Adverse Drug Event and Reports [RADAR] project. Blood 2009; 113(20): 4834-4840. Dostupné z DOI: <http://dx.doi.org/10.1182/blood-2008-10-186999>.

20. Tuccori M, Focosi D, Blandizzi $C$ et al. Inclusion of rituximab in treatment protocols for non-Hodgkin's lymphomas and risk for progressive multifocal leukoencephalopathy. Oncologist 2010; 15(11): 1214-1219. Dostupné z DOI: <http://dx.doi.org/10.1634/ theoncologist.2010-0098.

21. Clifford DB, Ances B, Costello $C$ et al. Rituximab-associated progressive multifocal leukoencephalopathy in rheumatoid arthritis. Arch Neurol 2011; 68(9): 1156-1164. Dostupné z DOI: <http://dx.doi. org/10.1001/archneurol.2011.103>.
22. Teramoto $T$, Kaneko $H$, Funato $M$ et al. Progressive multifocal leukoencephalopathy in a patient with X-linked agammaglobulinemia. Scand J Infect Dis 2003; 35(11-12): 909-910.

Juraj Sokol, M.D., PhD.

هjuraj.sokol@jfmed.uniba.sk

Department of Haematology and Transfusion Medicine, National Centre for Haemostasis and Thrombosis, Jessenius Faculty of Medicine in Martin, Comenius University in Bratislava, Slovakia

www.uniba.sk

Doručeno do redakce 6. 3. 2016

Prijato po recenzi 13. 12. 2016
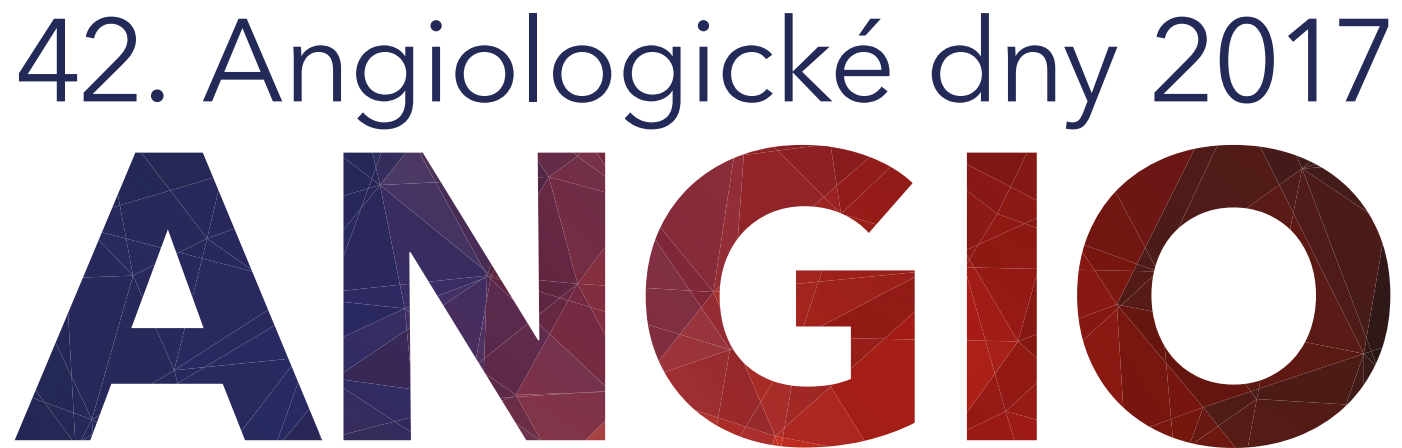

Kongres České angiologické společnosti ČLS JEP s mezinárodní účastí

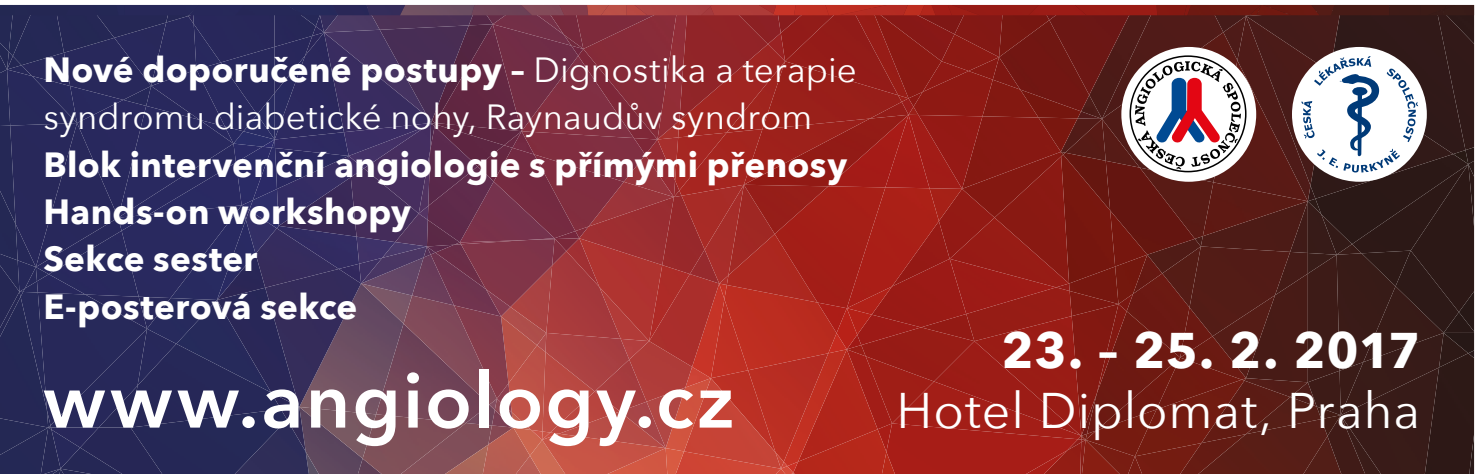

